\title{
Reduction of Energy Consumption in the Siberian Agricultural and Food Sector: Priority Measures
}

\author{
Chirkova Irina \\ Department of Industrial management and \\ Economics of energy \\ Novosibirsk State Technical University \\ Novosibirsk, Russia \\ e-mail: chirkova@corp.nstu.ru \\ Kulazhenok Igor \\ Department of Industrial management and \\ Economics of energy \\ Novosibirsk State Technical University \\ Novosibirsk, Russia
}

\author{
Bolgov Alexey \\ Department of Industrial management and \\ Economics of energy \\ Novosibirsk State Technical University \\ Novosibirsk, Russia
}

\author{
Pershukevich Peter \\ Siberian Research Institute \\ of Economic Management of Agriculture \\ Siberian Federal Scientific Centre of Agro-biotechnologies \\ of the Russian Academy of Sciences \\ Novosibirsk, Russia \\ e-mail: ecomomika@ngs.ru
}

\author{
Tyu Ludmila \\ Siberian Research Institute \\ of Economic Management of Agriculture \\ Siberian Federal Scientific Centre of Agro-biotechnologies \\ of the Russian Academy of Sciences \\ Novosibirsk, Russia
}

\begin{abstract}
Basing on the results of energy consumption monitoring during greenhouse vegetables and fish products production possibilities to reduce energy consumption have been determined. It can be done by investing into additional energy saving equipment, design changes in the main equipment stock, improving technological processes automation at the enterprises and utilization of local power sources. Fish processing manufacture modernization allows reducing energy consumption during cold production and in heat processes by $20-30 \%$. The identity of vegetable production energy-output ratio in Siberian sheltered ground and in innovative greenhouse complexes of countries with severe climate have been determined. Here changes in energy-output ratio by $1 \%$ with specific energyefficiency measures results in vegetable products cost reduction by $0.5-2 \%$. The most effective measures are: glass transparency increase, application of artificial supplementary lightning of plants.
\end{abstract}

Keywords - energy efficiency; heating; electricity use; costs; greenhouse vegetable production; fish processing

\section{INTRODUCTION}

There is instability in energy consumption for agri-food sector. This instability is caused by changes in local production technologies, simultaneous use of innovative and out-dated equipment, price variations for energy resources, natural and climate factors. During food production great amount of energy is spent on raw material processing, storage, transportation to the consumer. Energy consumption in agricultural sector is 18 percent; in processing sector is 82 per cent. Whereby a third of food is wasted together with about $38 \%$ of energy spent on its production [1]

Energy consumption efficiency enhancement can be achieved by material-technical base innovation. But this process is slow due to financial shortages. That is why new energy efficient equipment is introduced gradually with simultaneous adaptation of operational procedures and energy -efficient measures [2]. For this enterprises conduct energy consumption monitoring.

Newly created agri-industrial parks become especially significant as they provide enhanced possibilities of shared use of modern infrastructure and innovative equipment during food production to their residents [3]. Thus, local food production development saves country's food security and reduces prices at the local market due to production cost optimization $[4,5]$.

Providing balanced diet requires focusing attention on the production of the dietetic food such as fresh vegetables and fish products. Necessity to make such products economically available for the consumers all-year round in Siberia makes 
finding the ways of its production energy-output ratio reduction actual.

\section{MATERIALS AND METHODS}

Energy consumption efficiency in agri-food system was studied by empirical methods: observation, technological processes main parameters measuring, polling the specialists of enterprise energy service. Primary processing methods of the data received: balance, calculation, comparison and analogy. This approach to the agricultural production efficiency estimation based on energy consumption analysis is universal for comparing agri-technologies of different countries.

Estimating direct energy consumption for primary and secondary production operations was done at the enterprises with different production volume, technological level. Seasonal changes in energy consumption were noticed. Comparison of real energy consumption with average branch indexes in other countries with similar natural-climate conditions was done to determine competitiveness of the domestic product. The reasons for power resources loss in the production cycle were determined during the interview with experts (specialists of energy service).

Balance and calculation methods allowed determining food production energy efficiency and reasonability of energy saving measures by receiving data with instrument power measuring and from summary accounting records [6]. Economical efficiency of energy consumption for food production in agri-food sector proves energy efficient capacity and possibility to enhance system productivity.

\section{RESULTS AND DISCUSSION}

Dietic nutrition, with fresh fruit and fish, is necessary for healthy leaving. Vegetables are low-calorie, contain fiber for digesting, decrease body weight, cholesterol in the blood stream, intestines normal functioning, provide necessary vitamins and microelements. Fish and seafood are high protein with saturated fat. The highest content of omega 3 oils is in fatty fish such as salmon, tuna fish and trout.

Vegetable caloric value is lower in comparison with other products: tomatoes caloric value is $0.83 \mathrm{Mj} / \mathrm{kg}$, cucumbers $0.59 \mathrm{Mj} / \mathrm{kg}$, whereas that of fish is $3.6-5.9 \mathrm{Mj} / \mathrm{kg}$. At the same time greenhouse vegetable production energy consuming comparing to vegetable growing in the open. That is why protected horticulture is energy consuming agri production.

\section{A. Greenhouse vegetable production}

The world practice shows that population concern about health resulted in consuming more vegetables, especially by educated people who know about nutritious value of fresh vegetables in everyday life. Income increase and employment regime change influenced pattern of food consumption. With income increase people tend to substitute buying cheap vegetables, such as onion and cucumber by more expensive vegetables lettuce, cucumber, and tomatoes. Necessity for allyear round accessibility of local fresh vegetables determines reasonability of greenhouse vegetable production. Production development, its technological level and structure change due to peoples' needs change and state of the market.

There have been revolutionary changes for the last 20 years in greenhouse production: construction modifications of indoor structures; coating materials properties; automated plant nutrition; mulching; application of highly-bearing hybrids and kinds; plant preparation and clipping techniques; integrated pest control; insect pollinating; climate control; soil solarization and other technologies.

Less agri-organizations produce cucumbers and tomatoes in the open grounds as their bearing capacity is $2.5-3$ times lower in continental climate than in modern green houses. By increasing tomatoes bearing capacity from 12 to $38 \mathrm{~kg} / \mathrm{m}^{2}$ and that of cucumbers from 28 to $60 \mathrm{~kg} / \mathrm{m}^{2}$ decreased production energy-output ratio by $4-4.5$ times. Cucumbers $(67.7 \%)$ and tomatoes $(28.3 \%)$ are mostly grown in Russian industrial green houses. High cucumber share is explained by its wide application and it is a lucrative crop among sheltered ground vegetables in domestic manufacture as its growing process is well-studied and seed-stock is of wide range.

The level of greenhouse production prime cost depends on indoor structures. The prime cost in winter green houses is higher than in spring ones: for cucumbers it is $1.5-3.8 \%$, for tomatoes it is $44.8-57.4 \%$. It is explained by high maintenance fuel-energy costs in winter green houses. Using electrical power in heating processes of modern green houses is decreased due to its high cost and possibility of its substitution with other power sources. As most greenhouse facilities use natural gas and energy efficient equipment, fuel specific consumption has decreased for the last five years.

Greenhouse vegetable production is a highly technological agri-sector which is independent of environmental impacts. But in Siberia with severe climate for enhancing greenhouse production profitability it is necessary to use: more rational crop combination, providing maximal utilization of indoor structures all the year round; high breading, disease resistant, requiring less maintenance and having maximum productivity kinds and vegetable cross-breeds; energy-efficient microclimate systems.

Greenhouse facilities area in Siberia increase constantly, but severe climate constrains winter green house facilities widening. That is why nowadays we have the following rate of sheltered ground constructions: $28 \%$ are winter greenhouses, $72 \%$ are spring greenhouses.

The extreme climate factors condition additional impact on man-made systems. Thus, severe climate creates serious obstacles for effective vegetable production in sheltered ground, determining high heat and energy costs for indoor structures all the vegetation year round. High expenses are caused by supplementary lightning of plants and keeping optimal temperature regime in winter green houses that is why many green houses use extended crop combination. For example photo cultures are used in Finland when producing lettuce, cucumbers, and tomatoes. Yearly average power consumption are: heating $-11 \mathrm{Mj} / \mathrm{kg}$, lightning $-32 \mathrm{Mj} / \mathrm{kg}$ [7]. 
In countries with mild climate such as Turkey, the average power consumption for growing staple vegetables in greenhouses are estimated $50-106 \mathrm{Gj} / \mathrm{ha}$ at average breeding capacity about $160 \mathrm{t} / \mathrm{ha}$. Here the direct and subsidiary power consumption is for chemical agents $(10.19 \%)$, fertilizers $(27.59 \%)$, labour costs $(8.64 \%)$, fuel-power resources $(50.36 \%)$ [8]. Comparing with south regions in countries with temperate climate such as Germany, Holland, higher energy consumption is during greenhouse tomatoes production $(12654-15110 \mathrm{Gj} / \mathrm{ha}$, average breeding capacity is $480 \mathrm{t} / \mathrm{ha})$, cucumbers $(13053-14360 \mathrm{Gj} / \mathrm{ha}$, average breeding capacity is $750 \mathrm{t} / \mathrm{ha})$ and peppers $(10200-11539 \mathrm{Gj} / \mathrm{ha}$, average breeding capacity is $300 \mathrm{t} / \mathrm{ha}$ ) $[9,10]$.

In sheltered ground vegetable production in Norway and Canada, with the same severe climate as in Siberia there is intensive energy consumption. So, fuel-energy resources in the input energy flow for tomato production are $44 \%(15120$ $\mathrm{Gj} / \mathrm{ha})$, cucumbers - $39 \%(30600 \mathrm{Gj} / \mathrm{ha})$, lettuce - $22 \%$ $(23400 \mathrm{Gj} / \mathrm{ha})$ [11]. Green house technologies modification in Norway for the last 25 years allowed decreasing production energy output ratio from 54 to $33 \mathrm{Gj} / \mathrm{t}$ and increase breeding capacity almost 4 times.

The mast demanded and effective technological novelties in equipping, construction and greenhouse complexes modernization are: farming biologazation, interplanting technology, drip irrigation, LED-based lightning, hydroponic and airponic systems, cogeneration, innovative coverings and energy saving screens, evaporative cooling. According to the poll data of green house complexes specialists, nowadays innovations in power supply of greenhouse production and microclimate creation in sheltered ground constructions and lightning are especially popular (fig.1)

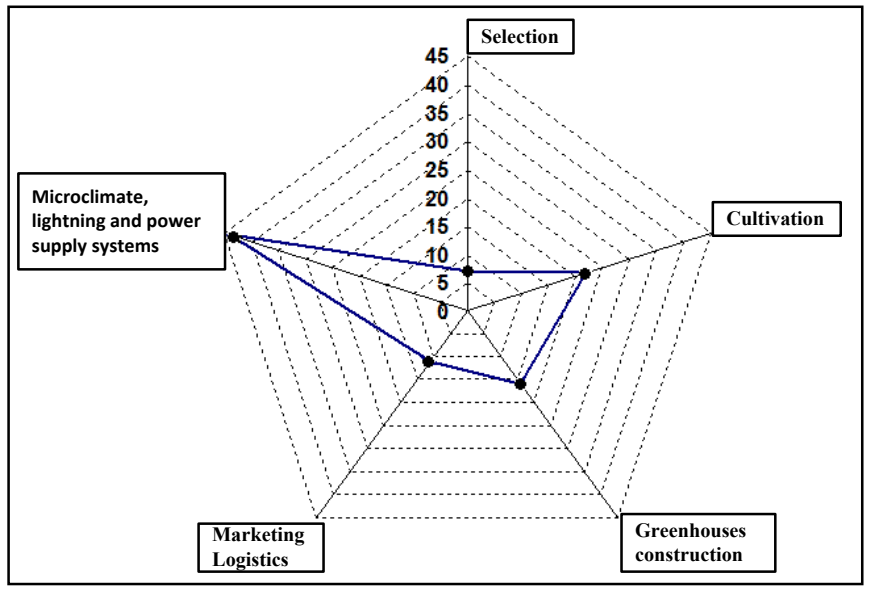

Fig. 1. Innovations distribution among sheltered ground vegetable production, $\%$

In the structure of total energy consumption of Russian green house complexes the larger amount is for direct energy consumption up to $80 \%$, sideway are $15 \%$, investment are $5 \%$. Production energy output ratio lowering firstly depends on the amount of direct energy consumption where heat energy consumption prevail and make more than $90 \%$ of total energy cost. On the example of two enterprises of sheltered ground vegetable production we will show annual energy consumption dynamics (table 1). These enterprises have different scales of sheltered ground vegetable production. In average annually green house complex "Novosibirskiy" produces $11790 \mathrm{t}$ of cucumbers and $3190 \mathrm{t}$ of tomatoes, "Priobskoe" produces $62 \mathrm{t}$ of cucumbers and $14 \mathrm{t}$ of tomatoes. That is why energy consumption rate and functioning differ.

TABLE I. DYNAMICS OF ENERGY CONSUMPTION FOR GREENHOUSE COMPLEXES OF NOVOSIBIRSK REGION

\begin{tabular}{|l|c|c|c|c|}
\hline \multirow{2}{*}{$\begin{array}{c}\text { Months } \\
\mathbf{2 0 1 7}\end{array}$} & \multicolumn{4}{|c|}{ Energy consumption, Gj } \\
\cline { 2 - 5 } & $\begin{array}{c}\text { LLC GHC “Novosibirskiy” } \\
\text { (17 ha) }\end{array}$ & $\begin{array}{c}\text { CJSC “Priobskoe” } \\
\text { (0.4 ha) }\end{array}$ \\
\cline { 2 - 5 } January & 29607 & 42453 & 855 & 925 \\
\hline February & 26273 & 27119 & 1773 & 1046 \\
\hline March & 21883 & 27782 & 1477 & 1278 \\
\hline April & 20502 & 26924 & 1484 & 1102 \\
\hline May & 9717 & 12642 & 1258 & 868 \\
\hline June & 1163 & 5892 & 610 & - \\
\hline July & 733 & 4136 & 450 & - \\
\hline August & 1007 & 11667 & - & - \\
\hline September & 15058 & 19158 & - & - \\
\hline October & 32113 & 40425 & - & - \\
\hline November & 28095 & 50570 & - & - \\
\hline December & 28504 & 48385 & - & - \\
\hline
\end{tabular}

GHC "Novosibirskiy" uses glass winter greenhouses and photo culture technology. It has stable power consumption costs which increase in winter and decrease in spring summer cultivation period. Concern power utilities include gas engine generators which decrease primary costs of the produced power by 2.2 times in comparison with the cost from outer sources. Besides, connecting via its own energy substation to high-voltage nets allows lowering energy costs. Further it is planned to obtain electrical power from wholesale market.

In cogeneration (CHP) plants for energy supply of greenhouse complexes the produced energy is spent on lightning, operational processes in the greenhouses, heat energy is spent for heating, carbon dioxide (exhaust fumes) is for plant nutrition for their development and breeding capacity increase. Recently, most greenhouse complexes introduce local systems based on gas engine generators which lower energy costs. But expenditures for these installations make about $30 \%$ of total cost for the complex.

"Priobskoe" has open ground and sheltered ground vegetable production. Cellular polycarbonate is used for green houses sheltering. Due to expensive glass this material thanks to its higher thermo - physical properties, greater strength, elasticity and durability is more profitable for small greenhouses than glass. Microclimat is kept with the systems of natural ventilation and air heating of greenhouse pavilion and soil with air heaters of direct fuel combustion with 
catalytic combustion materials clearing for carbon dioxide production. Due to the absence of the automated control of the production processes and assortment change (seedlings breeding) there are annual power sources consumption fluctuations.

Determining energy output ratio of the two complexes showed the following results: GHC "Novosibirskiy" (production: cucumbers, tomatoes, lettice) - $35.5 \mathrm{Gj} / \mathrm{t}, 31283$ Gj/ha, "Priobskoe" (production: cucumbers, tomatoes, seedlings) - $32815 \mathrm{Gj} / \mathrm{ha}$. Thus, the combinate, which has production with innovative technologies, is less competitive according to energy costs.

Vegetable production efficiency can be increased by energy-efficiency measures decreasing energy out-put ratio and production cost. It has been determined that energyefficiency change by $1 \%$ with different energy-efficiency measures reduces vegetable production cost by $0.5-2 \%$. The most flexible binding is with glass transparency increase $(2 \%)$, application of artificial supplementary plant lightning (1.6\%).

Thanks to new design and engineering solutions which solve the problem of low energy efficiency for the branch green house business is becoming more attractive. New capacities construction cost fluctuate from $0.9-1.7 \mathrm{mln}$ dol./ha. If investments into road construction, power supply network, water supply system are required than the cost increases upto $2.9 \mathrm{mln}$ dol./ha. The complex investments of area $10-20$ ha are paid back in $7-10$ years.

\section{B. Fish processing}

Nowadays the state of the agro-food market and providing food supply are global problems. Disbalance in food production and requirements in it relates to all the states and if it is not eliminated than it can be destructive for many countries [12]. The share of Russian food goods in the domestic market is about $77 \%$. In general $87 \%$ Russians prefer frozen fish products due to the low cost. Nevertheless, freezing and canning with further transportation add cost significantly and the final product can not be considered a cheap source of protein when it reaches the distant markets.

Global increase in fish production determines increase in its per capita consumption about $1 \%$ a year. Nowadays annual per capita consumption is $20.7 \mathrm{~kg}$. On the global scale $40 \%$ fish reaches the final consumer fresh. $60 \%$ of the global production volume is frozen, sun-dried, canned, used for fish flour or fish oil. $77 \%$ (about $68 \mathrm{mln}$ tons) of the processed fish is used for consumption, the rest is spent on non-food purposes. For greater keeping period freezing technologies are used, for processing $55 \%$ of all fish, $26 \%$ is canned and $8 \%$ is dried [13].

Fish cannery energy consumption can be divided into several production processes: about $60 \%$ of all the energy is spend for cold production (low temperature freezing chambers are for raw material and medium temperatures are for ready production), $23 \%$ is for fuming, $8 \%$ is for sun drying, $4 \%$ for fish canning and marinating, $3 \%$ is consumed by the workshop of preserves and pre-packed food, $2 \%$ is energy consumption by the workshop. Frozen production is an important stage of production from fishing to final product. Freezing allows increase the period of availability of big catches and weaken seasonal fluctuations in product supply [14].

When energy consumption at the enterprise in Novosibirsk region was studied specific costs shown in table 2 were recorded

TABLE II. ENERGY CONSUMPTION AT THE FISH PRODUCTION ENTERPRISE LLC "NOVOSIBIRSK FISH”

\begin{tabular}{|l|l|c|}
\hline \multicolumn{1}{|c|}{$\begin{array}{c}\text { Technological } \\
\text { process }\end{array}$} & \multicolumn{1}{|c|}{ Equipment } & $\begin{array}{c}\text { Electrical energy } \\
\text { consumption, (kWh/t) }\end{array}$ \\
\hline Storage & $\begin{array}{l}\text { Low temperature ammonia } \\
\text { refregirators }\end{array}$ & 870.5 \\
\hline $\begin{array}{l}\text { Cold smoking } \\
\text { turret type } \\
\text { smoke house) }\end{array}$ & $\begin{array}{l}\text { Smoke apparatus, electrical } \\
\text { heater for drying, vertical chain } \\
\text { transportation system }\end{array}$ & 483.3 \\
\hline $\begin{array}{l}\text { Salination and } \\
\text { marinating }\end{array}$ & $\begin{array}{l}\text { Salt concentrations for saline } \\
\text { solution }\end{array}$ & 66.7 \\
\hline Drying & $\begin{array}{l}\text { Air-circulating fans, electric } \\
\text { tens }\end{array}$ & 35.2 \\
\hline $\begin{array}{l}\text { Pre-packed and } \\
\text { preserves } \\
\text { preparation }\end{array}$ & $\begin{array}{l}\text { fish slicers and fish filleting } \\
\text { machines }\end{array}$ & \\
\hline
\end{tabular}

First of all it is necessary to reduce electrical energy consumption for storage and ready production by using more energy efficient aggregates based on compressors Frascold that will decrease energy consumption by $400-600$ thousand $\mathrm{KWh}$ per year, which is a significant resource economy for the enterprise. Also the company plans to buy a fish washing machine to improve the quality of fish washing, salt concentrator, and a new slicer for fish cutting, salination workshop reconstruction, smoking workshop modernization. The improvements will increase energy efficiency of the production as well as production secure. The total costs of modernization will be about 70 thousand dollars [15].

\section{CONCLUSION}

The issue of energy efficiency is important. It will allow efficient use of fuel-power resources, minimizing energy costs and enhancing competitiveness of the agro-food sector. Way of living and customers' preferences determine energy consumption. On the one hand, requirement for processed and ready to use production determines all-the -year round accessibility of fresh products.

Food production systems differ significantly in energy consumption and energy efficiency potential. It means that the ways to save energy are numerous. But at this stage the key elements of power consumption efficiency increase of using energy in agrarian and food sectors of Siberia are: power managing infrastructure, constant monitoring of energy efficiency; material and technical base renovation and wider introduction of innovative technologies. Energy -efficient strategy is based on estimating possibilities for reconstruction of production system for power consumption decrease and determining priority actions; determining aims, periods of certain measures and choosing evaluation methods; determining obstacles for investments into energy efficiency of the enterprise and ways to overcome them. 


\section{References}

[1] R. Sims, A. Flammini, M. Puri, S. Bracco, "Opportunities for Agri-Food Chains to Become Energy-Smart", Retrieved from: http://www.fao.org/3/a-i5125e.pdf.

[2] J.Vourdoubas, O.Dubois "Energy and Agri-Food Systems: Production and Consumption", Retrieved from: http://ciheam.org/uploads/attachments/445/07_Mediterra2016_EN.pdf.

[3] I.G. Chirkova, A.S. Osadchii, K.V. Nefatova, "Urban Economy Development Based on Utilizing the Potential of Industrial Parks", Studies on Russian Economic Development, 2018, Vol. 29, No. 4, pp. 387 - 391. - DOI: 10.1134/S1075700718040056

[4] K. Borodin, A. Strokov, "The Customs Union in the CIS", Journal of Economic Integration, 2015, Vol. 30, No 2, pp. 334- 358, DOI: $10.11130 /$ jei.2015.30.2.334

[5] K. Borodin, "The impact of the embargo and sanctions on the agri-food markets in Russia: Analysis of consequences", Voprosy Ekonomiki, 2016, No. 4, pp. $124-143$

[6] A. A.Tupikina, S. S. Chernov, "Energy service agreement as a tool of the program implementation aimed at raising of energy efficiency: challenges and opportunities", E3S Web of Conferences, 2016, Vol. 6: International Conference on Sustainable Cities, Art. 03002, DOI: $10.1051 / \mathrm{e} 3$ sconf $/ 20160603002$.

[7] T. Kaukoranta, "Effects of lighting, semi-closed greenhouse and splitroot fertigation on energy use and $\mathrm{CO}_{2}$ emissions in high latitude cucumber growing", $\quad$ Retrieved from: https://journal.fi/afs/article/download/8682/13855/.
[8] Food and Agricultural Organization of the United Nations, "Good Agricultural Practices for greenhouse vegetable crops", Retrieved from: http://www.fao.org/3/a-i3284e.pdf.

[9] M. Taki, H. Yildizhan, "Evaluation the sustainable energy applications for fruit and vegetable productions processes; case study: Greenhouse cucumber production”, Journal Of Cleaner Production, 2018, Vol. 199, pp. 164-172, DOI: 10.1016/j.jclepro.2018.07.136

[10] T. Bosona, G. Gebresenbet, "Life cycle analysis of organic tomato production and supply in Sweden", 2018, Vol. 196, pp. 635-643, DOI: 10.1016/j.jclepro.2018.06.087.

[11] B. Grace, R. P. Zentner, "Energy Consumption in the Canadian Agricultural and Food Sector", Retrieved from: http://www.usask.ca/agriculture/caedac/PDF/energy_95.PDF.

[12] E. Rudoy, M. Stasiulis, A. Samokhvalova, M. Vyshegurov, L. Iakimova, "Development of agrofood market in the southern part of Siberia by means of regional and food relations", International Journal of Applied Business and Economic Research, 2016, Vol. 14, No. 9, pp. 5875-5890.

[13] C.J. Backi "Methods for (industrial) thawing of fish blocks: A review", 2018, Vol. 41, No 1, DOI: 10.1016/j.jclepro.2018.06.087.

[14] Food and Agricultural Organization of the United Nations, "Assessment and management of seafood safety and quality", Retrieved from: http://www.fao.org/3/a-i3215e.pdf

[15] I. N. Kulazhenok, "Organizational and economic aspects of modernization of fish-processing enterprises", Business. Education. Law, 2018, Vol. 44, No. 3, pp. 238-243, DOI: 10.25683/VOLBI.2018.44.307. 